Zoran M. Karastojković ${ }^{1 *}$, Suzana R. Polić ${ }^{2}$, Milesa Ž. Srećković ${ }^{3}$, Nataša A. llić ${ }^{2}$, Zoran V. Janjušević ${ }^{4}$

${ }^{1}$ Technical college, Novi Beograd, Serbia, ${ }^{2}$ Central institute for conservation, Belgrade, Serbia, ${ }^{3}$ University of Belgrade, Faculty of electrical engineering, Belgrade, Serbia, ${ }^{4}$ Institute for technology of nuclear and other mineral raw materials, Belgrade, Serbia
Scientific paper

ISSN 0351-9465, E-ISSN 2466-2585

UDC:620.152.1:620.183.4/.6

doi: $10.5937 /$ ZasMat $1702158 \mathrm{~K}$

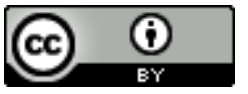

Zastita Materijala 58 (2)

$158-162(2017)$

\title{
X-ray transparent testing of leaves from an artistic desk lamp
}

\begin{abstract}
For investigation of artistic components, generaly, there are many developed methods, but a lot of them still are not fully reliable or standardized. One of the available method for such investigation is radiographic testing, when the thickness of testing components does not represents a problem, whatever if the great or small thickness exists. Here is tested an artefact in the shape of desk lamp. The chemical composition of the body is analysed by using XRF spectrography while the radiographic transparent testing is applied through the whole body of the lamp.

The body of this desk lamp is produced by casting, using the precise casting method, while other decorative ornaments were shaped by hammering. The fastening of those components is provided by brazing or mechanically. The plastic deformation is designated as method for shaping of thin elements - here leaves. The radiographic testing has revealed the existence of some indications only at leaves produced by hammering. The indications usualy mean discontinuity in material homogenity. Registration of indications and their locations are necessary steps in every further approach for removing such discontinuities. Chossing the repair method always is particular problem, however in entire technique, especially in sensitive artistic component(s). Every action in repairing or restauration may led to more or less visible traces. Unadequate actions may permanently change the appearance or usage of treated artefact.
\end{abstract}

Keywords: artistic castings, radiographic testing, indications at leaves.

\section{INTRODUCTION}

Several studies have indicated that, when is used X-ray diagnostic methods in conjunction with art, historical and technical knowledge of artistic works than will impact on change the understanding of art objects given by curators based on stylistic features [1-3]. Although a few museums have been examined their sculptures, in more or less systematic way, still exists the relatively small number of results of X-ray diagnostic methods of sculpture collections. It means that our resource and/ knowledge of comparative data for studying the techniques and materials in area sculpture are limited. Therefore, it is important to analyze the shape and homogenity of sculptures, particilarly in casted components, as in here examined sculpture. The examined casted component is one from a greater number similar sculptures made by

\footnotetext{
*Corresponding author: Zoran Karastojković

E-mail: zoran.karastojkovic@gmail.com

Paper received: 23. 12. 2016.

Paper accepted: 24. 01. 2017.

Paper is available on the website:

www.idk.org.rs/journal
}

Auguste Moreau, Fig. 1a), or others, Fig 1b). In particular case a neutron transparent tehnique may be used, Fig. 1c), for analizing a homogenity.

Any kind of investigation of an artistic component always represents a serious problem, because even a small damage during testing may have produce the catastrophic influence on reliability of tested component. The restauration on the begining position of damaged artictic component frequently simply is imposible. So, the investigation of an artistic component should be provided on very carefully manner, of course with specific knowledge. Commonly, the used material of an artistic component is rather unknown, but the material properties are worthy to know [4-7]. It seems that minimized number of standardized methods will be available for testing of an artistic component.

Here are applicable only a few testing methods, which could not destroy the tested component - in this case it is desk lamp form XIX century, designed by French artist Auguste Moreau. Two views of investigated desk lamp, $41 \mathrm{~cm}$ hight, are shown in Figs. 2a) and b). Before providing any kind of testing the desk lamp is however visually monitered. 

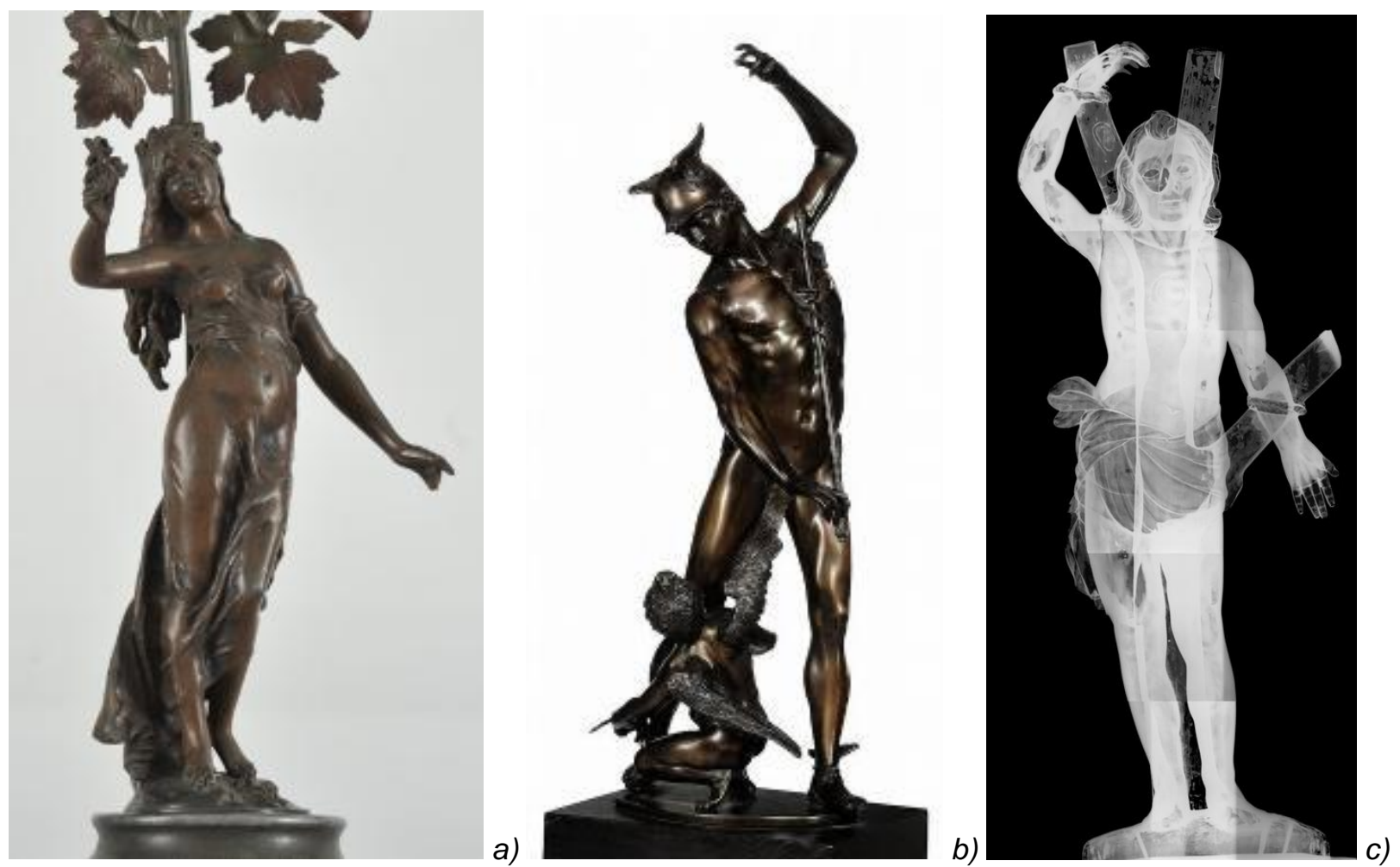

Figure 1. a) Auguste Moreau: desk lamp; b) Adriaen de Vries: Mercury, Augsburg; c) transparent neutron technique used for analyzing of Saint Sebastian of the Church of Capuchin Friars, Rio de Janeiro. Slika 1. a) August Moro: stona lampa; b) Adrijan de Vries: Mrkur, Augsburg; c) neutronska tehnika prozračivanja za analizu statue San Sebastijana ${ }^{3}$ iz crkve Kapučin Friars, Rio de Žaneiro
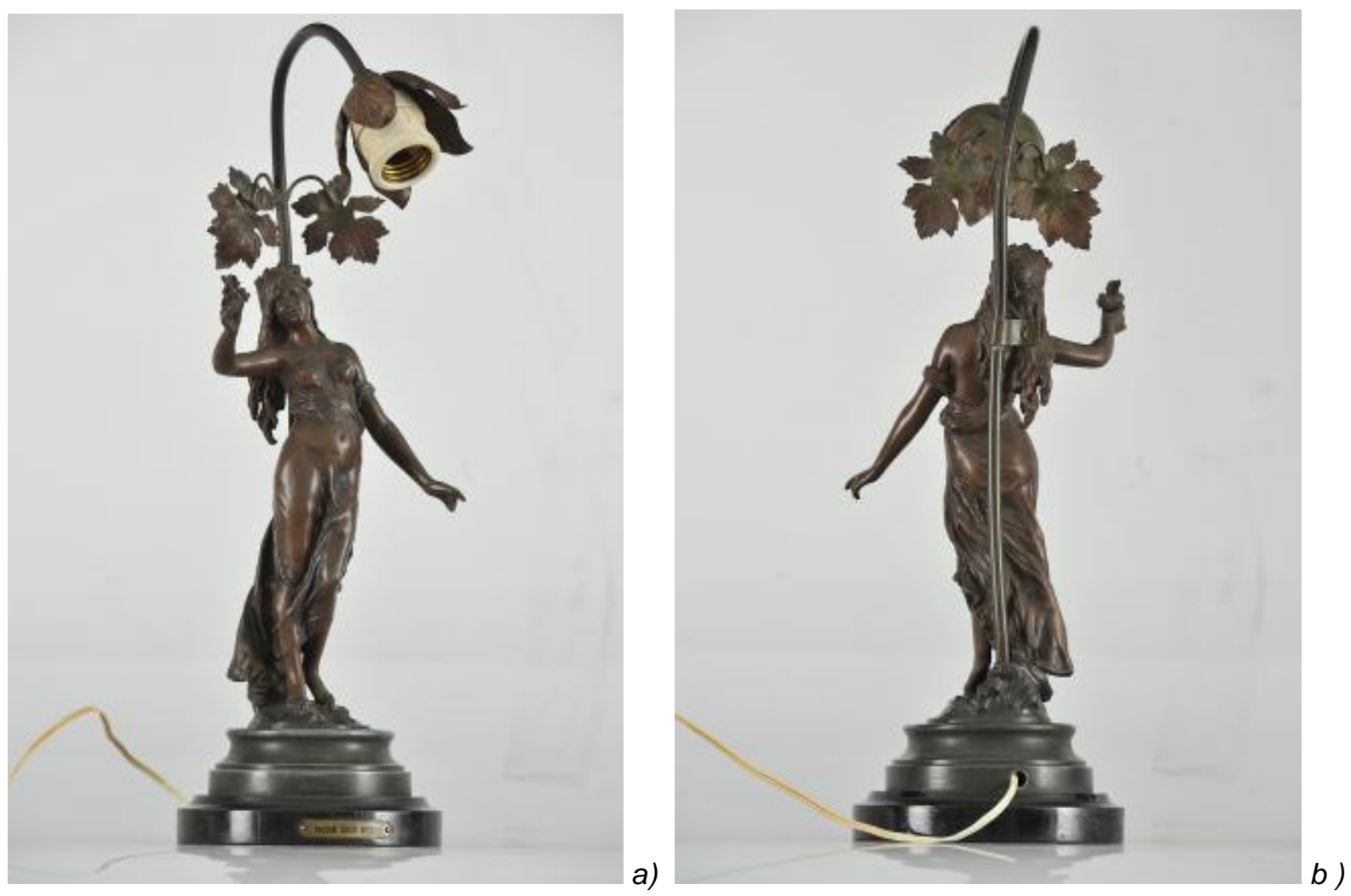

Figure 2. Front a) and back) b) view of investigated desk lamp, XIX century Slika 2. a) Pogled spreda i b) otpozadi ispitivane stolne lampe, XIX vek 
For testing of chemical composition of the desk lamp a XRF method is chosen [8,9] but for the discovering of irregularities, i.e. cracks, a X-ray transparent method is used $[10,11]$. The entire outer surface of the desk lamp was protected in dark brown color against corrosion.

\section{CHEMICAL ANALYSIS}

For providing a chemical analysis principally several methods are available, one of them is the gravimetric method, but in this procedure relatively large amount of material from a small/thin part must be taken, it means destroyed. Such destroying of a tested element simply is not allowed when an artistic element is analyzed. From that reason the X-ray fluoroscence (XRF) method is chosen, when only a little spot is affected [7-11].

The chemical analyze on tested artefact is provided on two places, when spot trails will not be visible. Those spots were at the positions (m.m1 and 2) as shown in Fig. 3.

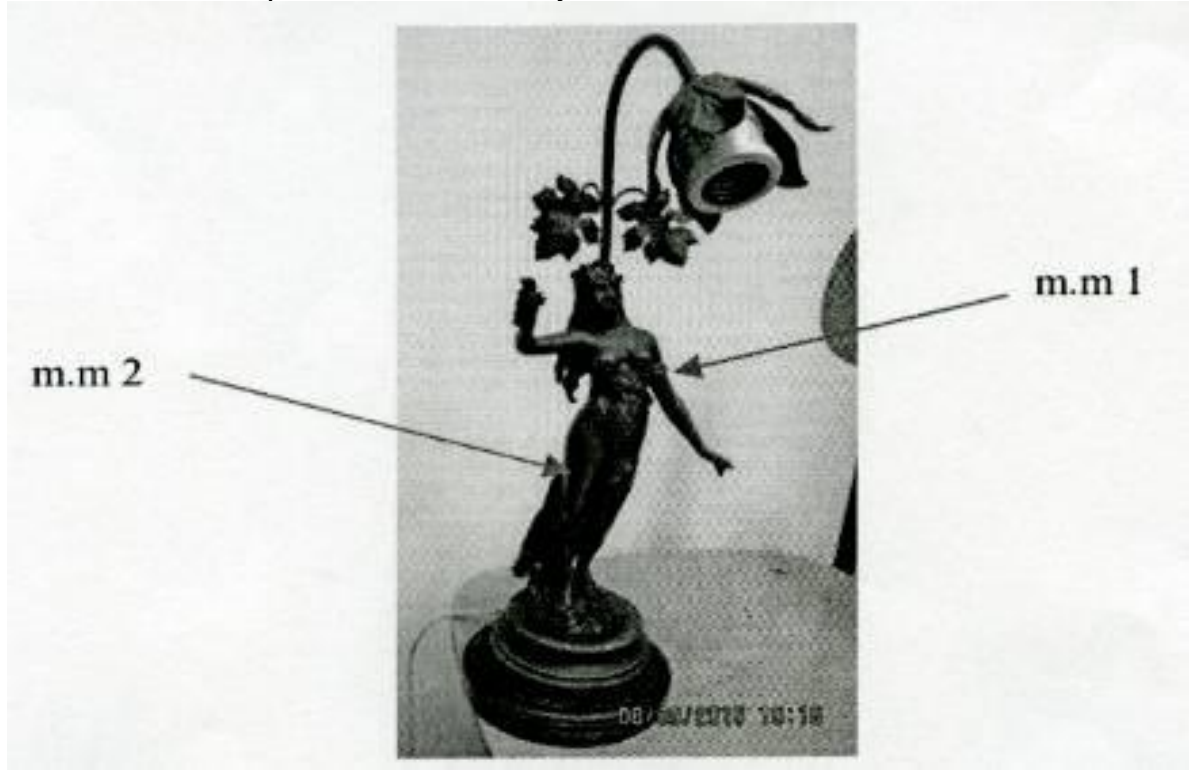

Figure 3. Positions of XRF testing at desk lamp

Slika 3. Položaji rendgenskog ispitivanja stolne lampe

$\mathrm{X}$-ray fluorescence (XRF) spectrometry, as an elemental analysis technique with broad application in science, industry or archeology, was used in the determination of both major and trace elements in Table 1. XRF analysis at body of desk lamp [8], mass \%

Tabela 1. Rendgenska fluoroscentna analiza tela stolne lampe [8], mass \%

\begin{tabular}{|c|c|c|c|c|c|c|c|c|c|c|c|}
\hline $\begin{array}{c}\text { Posi- } \\
\text { Tion }\end{array}$ & $\mathrm{Sb}$ & $\mathrm{Sn}$ & $\mathrm{Ag}$ & $\mathrm{Pb}$ & $\mathrm{Zn}$ & $\mathrm{Cu}$ & $\mathrm{Fe}$ & $\mathrm{Cr}$ & $\mathrm{Ti}$ & $\mathrm{P}$ & $\mathrm{Si}$ \\
\hline $\mathrm{m} . \mathrm{m} 1$ & 0.011 & 0,003 & 0,167 & 1,076 & 90,908 & 6,286 & 0,245 & 0,188 & 0,062 & 0,026 & 0,076 \\
\hline $\mathrm{m} . \mathrm{m} 2$ & 0.049 & 0,033 & 0,019 & 2,136 & 89,585 & 5,041 & 0,631 & 0,275 & 0,056 & 0,631 & 1,231 \\
\hline
\end{tabular}

Note: Testing is provided at Laboratory of Welding institute, Belgrade

Tested alloy with $\approx 90 \% \mathrm{Zn}$ belongs to a group of zinc casting alloys, with copper as a major alloying element. As minor alloying elements small amounts of tin were recorded, while the presence of silicon was varied from 0,076 to $1,231 \%$, compare results from m.m1 and m.m2.

\section{X-RAY TRANSPARENCY}

$X$-ray transparency is an available method for nondestructive testing of artefacts with a complex shape/geometry. The body of examined desk lamp variety of materials [8-13]. Results of applied XRF analysis on desk lamp body alloy are presented in Table 1, here are shown important elements from 18 tested elements. possess complex geometry, as could be seen from Fig. 4. The central part of desk lamp with leaves represent the positions to be tested. The massive part of the desk lamp is produced by casting while the leaves were produced from a thin sheet. Those leaves are too sensitive for chemical composition determination, from a reason of destroying them.

Leaves are brazed onto the thin dendrite arms, also visible at the same figure.

The image recorded on photo plate by using $X$ ray transparent technique is shown in Fig. 5 . 


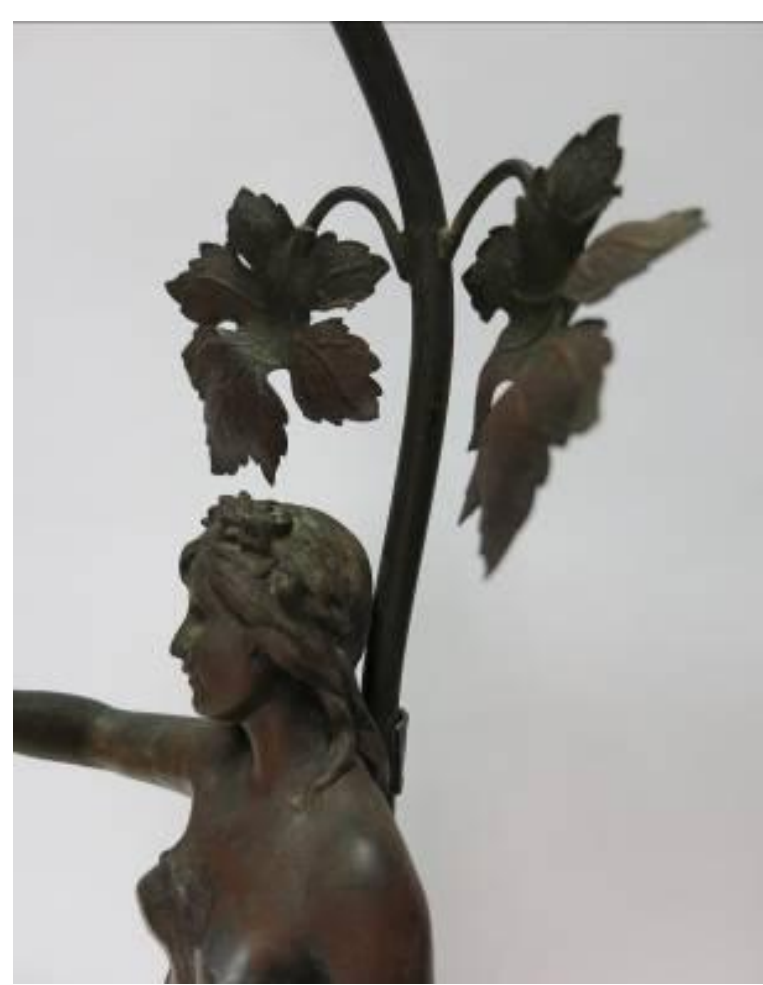

Figure 4. Part of desk lamp of interest for testing

Slika 4. Deo stolne lampe od važnosti za ispitivanje

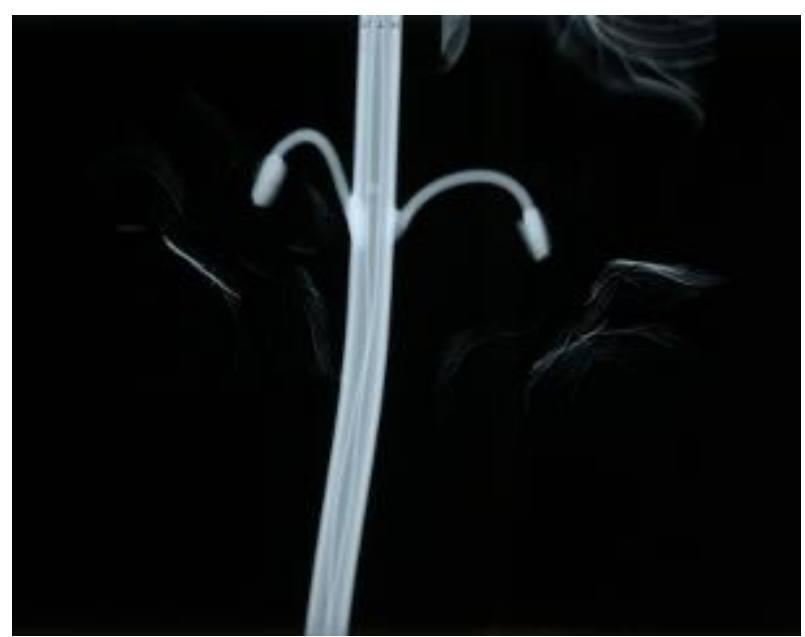

Figure 5. X-ray film of central part of desk lamp with leaves ( $\approx 1 \mathrm{~mm}$ in thickness)

Slika 5. Rendgenski film centralnog dela stolne lampe sa lišćem ( $\approx 1 \mathrm{~mm}$ debljine)

At leaves, Fig. 5 , are visible indications as a thiny $(\approx 0.5 \mathrm{~mm}$ or less) white curved lines.

\section{DISCUSSION}

The investigated desk lamp is produced by casting, brazing and mechanical operations, while the surface is (electro)chemically treated to be corrosive resistant and for decorative reasons. The complex shaped body of observed desk lamp is produced by casting. At the examined positions is found a high contest of zinc, at level about $90 \%$, and relatively small amount of copper $(\approx 5,5 \%)$, see Table 1. Such percents of zinc and copper in the alloy from desk lamp are not customized in modern casting technology [4-7]. The presence of tin and silicon in relatively small amounts may be considered as accidental or unintentional $[4,8,9]$.

Thin leaves, about $1 \mathrm{~mm}$ in thickness, from the investigated desk lamp, could not be produced by casting method but using a kind of deforming method [12-14]. The hammering of those leaves is predicted as potential method for their shaping. Further metallographic investigation may help in explanation of used technology (hammering) in leaves shaping. The hammered leaves further are brazed onto the central arm of desk lamp.

If eventually are visible any kind of crack(s) on obtained X-ray film, as here, the registered indications may however serve for further engineering analyze of a production method and kind(s) of faults through the entire body, even when the artistic part is an object of observation or investigation [1-15]. But, irregularities visible from Fig. 4. need more detail analyze by applying a kind of more sensitive method.

The surface protection frequently is applying on such parts $[7,16]$, and this fact may have led to misunderstanding about the thrue chemical composition of the bulk material, i.e. entire body of investigated artefact. The protection layer was homogeneous through the entire surface.

\section{CONCLUSION}

The components from observed desk lamp are produced by casting, hammering and brazing. A few components of this desk lamp are mechanicaly attached. The XRF spectral analysis has shown that the body of desk lamp is produced from an alloy with high contest of zinc $(\approx 90 \%)$, with copper $(\approx 5,5 \%)$ as a major alloying element, and minor contest of tin and silicon. This is not a common alloy in the casting technology.

The type of surface protection layer through the entire desk lamp was well chosen and applied.

Film obtained by X-ray transmision technique has shown the presence a kind of indications only at leaves. More sensitive testing techniques should be further applied for better understanding the nature of here registered and shown irregularities.

\section{Aknowledgement}

We kindly gratitude to Institute for welding, Belgrade, for help in determination of chemical composition. This research was financially supported by the Ministry of Education, Science and Technological Development of Serbia under Projects TR-34028. The authors especially thank the Ministry of Culture and Information of Serbia. 


\section{REFERENCES}

[1] C.Calzaa, D.F.Oliveiraa, R.P.Freitasc, H.S.Rochaa, J.R.Nascimentoa, R.T.Lopesa (2015) Analysis of Sculptures Using XRF and X-ray Radiography, Radiation Physics and Chemistry, 116, 326-331.

[2] J.Bassett (2008) An Opportunity taken: the project design for a technical study of 26 bronzes in the exhibition adriaen de vries: imperial sculptor at the J. Paul Getty museum, Objects specialty group postprints, Volume Nine, p. 68-78.

[3] R.Van Langh, E.Lehmann, S.Hartmann, A Kaestner, F.Scholten (2009) The Study of Bronze Statuettes with the Help of Neutron-imaging Techniques, Analytical and Bio-analytical Chemistry, 395(7), 1949-1959.

[4] B.Kočovski (1967) Metallurgy of Non-ferrous Metals, Serbian, Bor, Faculty of Mining and Metallurgy, p. 28-174.

[5] Lj.Ivanić (2000) Casting, Technical Faculty Bor, University of Belgrade, in Serbian, Bor, p. 53-137.

[6] S.Marković, V.Radovanović, Ž.Kamberović (2005) Artistic Casting, in Serbian, Belgrade, Klasa d.o.o, p. 11-68.

[7] M.Barjanovskij, A.Dmitrovič, N.Intjakov, V.Čajka (1966) Handbook for techno-logists, Russian, Minsk, Belarus, p.47-205.
[8] A.M.Wasserman, V.A.Danilkin, O.S.Korobov (1985) Methods of Control and Testing of Light Metals, Moscow, Russian, Metallurgiya, p. 61-64.

[9] J.C.Vickerman (1997) Surface Analisis - The Principal Techniques, Chichester-England, John Wiley\&Sons, p. 46-49; p.371-389.

[10] I.Aničin, A.Fertilio, M.Nikolić (1988) Radiography Principles and Testing Methods, in Serbian, Belgrade, Institut za nuklearne nauke Vinča, p. 91 182.

[11] R.E.Shoy, M.S. van Lysel, M.J.Yaffe (1995) X-ray Equipment, Handbook Biomedical Engineering, Hartford-Connecticut, USA, CRS Press, IEEE Press, p. 953-972.

[12] K.N.Bogojavljenskij, V.V.Žolobov (1973) Deformation of Non-ferrous Metals and Alloys, Russian, Moscow, Metallurgiya, p. 217-434.

[13] G.I.Beljčenko, S.I.Gubenko (19870 Principles of Metallography and Working Processes of Steels, Russian, Kiev-Doneck, Višča škola, p. 42-119.

[14] I.K.Suvorov (1973) Metal Working Processes, Russian, Moscow, Visšaya škola, p. 228-375.

[15] S.Petrić, S.Polić, D.Jovanović, N.llić, V.Živković, V. Džikić (2015) Conservation of Silver Belt Type „Mramorac“, Serbian, Belgrade, Centralni institut za konzervaciju u Beogradu i Zavičajni muzej Jagodina, p. 5-27.

[16] Z.Karastojković (2016) Surface Protection of Metals, Serbian, Belgrade, Visoka tehnička škola strukovnih studija - Novi Beograd, p. 79-100.

\title{
IZVOD
}

\section{RENDGENSKO ISPITIVANJE PROZRAČIVANJEM LISTOVA SA JEDNE UMETNIČKI OBLIKOVANE STOLNE LAMPE}

\begin{abstract}
Za ispitivanje umetničkih predmeta, uopšte, razvijene su brojne metode ali sve te metode još uvek nisu potpuno pouzdane ili standardizovane. Jedna od primenljivih metoda za ovakva ispitivanje je radiografsko ispitivanje, kada debljina ispitivanih delova ne predstavlja problem, bilo da se radi o velikoj ili maloj debljini. Ovde je ispitivan jedan umetnički predmet u obliku stolne lampe. Hemijski sastav tela je analiziran korišćenjem rendgenske spektrografske analize (XRF) dok je rendgensko prozračivanje upotrebljeno za snimanje celog tela lampe.

Telo lampe je proizvedeno livenjem, korišćenjem metode preciznog liva, dok su ostali dekorativni ornamenti oblikovani kovanjem. Pričvršćivanje ostalih komponenti je izvedeno lemljenjem ili mehanički. Plastično deformisanje je označeno kao metoda oblikovanja tankih elemenata - ovde su to listovi. Radiografsko ispitivanje je otkrilo prisustvo izvesnih indikacija samo na listovima izrađenih kovanjem. Indikacije obično označavaju prekid u homogenosti materijala. Registrovanje indikacija i njihovo lociranje su neophodni koraci u svakom daljem pristupu u cilju uklanjanja takvih diskontinuiteta. Izbor metode repariranja uvek je poseban problem, dakako u celoj tehnici a posebno pri ispitivanju umetničkih komponenti. Svaka akcija u reparaciji ili restauraciji može dovesti do manje ili više vidljivih tragova. Neadekvatne akcije mogu za stalno da promene izgled ili upotrebu tretiranog artefakta.
\end{abstract}

Ključne reči: umetnički odlivak, radiografsko ispitivanje, indikacije na listovima.

Naučni rad

rad primljen: 23. 12. 2016.

Rad prihvaćen: 24. 01.2017.

Rad je dostupan na sajtu: www.idk.org.rs/casopis

(c) 2017 Authors. Published by Inženjersko društvo za koroziju. This article is an open access article distributed under the terms and conditions of the Creative Commons Attribution 4.0 International license (https://creativecommons.org/licenses/by/4.0/) 